\title{
PENINGKATAN KEMAMPUAN KOSA KATA MELALUI KEGIATAN BERMAIN PERAN PADA ANAK USIA DINI
}

\author{
Miftahuljannah \\ TK Al-Amin Palopo
}

Email: miftahuljannahy24@gmail.com

Orcid Id: https://orcid.org/0000-0002-4640-5527

$\begin{array}{ll}\text { Article received } & : 2021-10-25 \\ \text { Review process } & : 2021-11-19 \\ \text { Article published } & : 2021-12-27\end{array}$

\begin{abstract}
The problem in this study is that children's vocabulary skills are still difficult to speak. This study aims to determine the increase in vocabulary skills through role playing activities in group A children at AlAmin Kindergarten, Palopo City. The type of research used is classroom action research. Data collection techniques through observation, interviews, and documentation. The data analysis technique used is descriptive qualitative and quantitative analysis techniques. The results showed that role playing activities can improve children's vocabulary skills. The improvement can be seen in the research results. In the initial condition, there were five children (50\%) in the $B B$ category, three children (30\%) in the MB category, two children (20\%) in the BSH category. After taking action in cycle I the results in children's vocabulary skills through role playing activities have increased, namely there is one child (10\%) in the BB category, there are two children (20\%) in the MB category, five children (50\%) in the BSH category and two children (20\%) in the BSB category. In the second cycle, there were no children in the BB and $M B$ categories, seven children (70\%) in the BSH category and three children (30\%) in the BSB category. This research was stopped until the second cycle because the criteria for success indicators had been achieved.
\end{abstract}

Keywords: Role-Play, Vocabulary Skills.

\section{Abstrak}

Permasalahan pada penelitian ini tentang kemampuan kosa kata anak masih kesulitan dalam berbicara. Penelitian ini bertujuan untuk mengetahui peningkatan kemampuan kosa kata melalui kegiatan bermain peran pada anak kelompok A di Taman Kanak-kanak Al-Amin Kota Palopo. Jenis penelitian yang digunakan adalah penelitian tindakan kelas. Teknik pengumpulan data melalui teknik observasi, wawancara, dan dokumentasi. Teknik analisis data yang digunakan adalah teknik analisis deskriptif kualitatif dan kuantitatif. Hasil penelitian menunjukkan bahwa kegiatan bermain peran dapat meningkatkan kemampuan kosa kata anak. Peningkatan dapat dilihat pada hasil penelitian. Pada kondisi awal terdapat lima anak (50\%) dalam kategori BB, tiga anak (30\%) dalam kategori MB, dua anak (20\%) dalam kategori BSH. Setelah dilakukan tindakan pada siklus I hasilnya pada kemampuan kosa kata anak melalui kegiatan bermain peran mengalami peningkatan yaitu terdapat satu anak (10\%) dalam kategori BB, terdapat dua anak (20\%) dalam kategori MB, lima anak (50\%) dalam kategori BSH dan dua anak (20\%) dalam kategori BSB. Pada siklus II meningkat menjadi tidak terdapat anak dalam kategori BB danMB, tujuh anak (70\%) dalam kategori BSH dan tiga anak (30\%) dalam kategori BSB. Penelitian ini dihentikan sampai siklus II karena kriteria indikator keberhasilan telah tercapai. 
Kata Kunci: Bermain Peran, Kemampuan Kosa Kata. 
Setiap anak memiliki potensi yang dapat dikembangkan dalam setiap jenjang Pendidikan. Karena Pendidikan merupakan tempat yang tepat bagi anak dalam mengembangkan segala potensi yang dimilikinya dan sangat dibutuhkan anak untuk persiapan dalam menghadapi masa depannya. Pendidikan untuk anak usia pra sekolah disebut Pendidikan Anak Usia Dini (Paud).

Melalui satuan PAUD, anak diberikan rangsangan atau stimulasi pendidikan yang sesuai dengan pertumbuhan dan perkembangan anak, agar anak menjadi lebih matang dan siap dalam menghadapi dunia sekolah lebih lanjut dan masa-masa kedepannya. Sebagaimana dinyatakan dalam Undang-Undang Republik Indonesia Nomor 20 tahun 2003 tentang sistem Pendidikan Nasional pada Pasal 1 ayat 14 menyatakan bahwa Paud adalah suatu upaya pembinaan yang ditujukan kepada anak sejak lahir sampai usia enam tahun yang dilakukan melalui pemberian rangsangan Pendidikan untuk membantu pertumbuhan dan perkembangan jasmani dan rohani agar anak memiliki kesiapan dalam memasuki Pendidikan lebih lanjut.

PAUD merupakan satuan yang membentuk pertumbuhan dan enam aspek perkembangan, yaitu : aspek perkembangan nilai agama dan moral, fisik-motorik, sosio-emosional, bahasa, dan seni. Salah satu aspek yang penting yaitu aspek perkembangan Bahasa karena melalui Bahasa dengan kemampuan kosa kata, anak dapat mengkomunikasikan maksud, tujuan, pemikiran maupun perasaannya kepada orang lain.

Menurut Cahyani dalam Nurfauziah (2013:1-2) mengemukakan bahasa merupakan alat untuk berkomunikasi. Melalui bahasa manusia dapat berinteraksi dan berkomunikasi mengemukakan hasil pemikirannya dan gagasan baik melalui bahasa lisan maupun bahasa tulisan serta dapat mengekspresikan perasaannya. Anak-anak belajar bahasa melalui interaksi dengan lingkungannya baik lingkungan rumah, sekolah, atau masyarakat. Melalui berbahasa, seseorang atau anak akan dapat mengembangkan kemampuan bergaul (social skill) dengan orang lain.

Berbahasa tidak akan pernah terlepas dari kosa kata. Kosa kata merupakan alat utama yang harus dimiliki seseorang dalam belajar bahasa yang berfungsi untuk mengungkapkan ide atau gagasan. Menurut Soedjito dan Saryono dalam Widiyaningsih (2017:13) Kosa kata adalah pembendaharaan kata atau kekayaan kata yang dimiliki oleh suatu bahasa. Penguasaan kosa kata dapat mempengaruhi keterampilan berbahasa seseorang.

Menurut Djiwandono dalam Markus, dkk (2017:104) mengatakan bahwa penguasaan kosa kata dapat dibedakan dalam penguasaan aktif-produktif dan pasifreseptif. Pengertian penguasaan kosa kata aktif-produktif yaitu kosa kata yang telah dikuasai dan dipahami, dapat digunakan oleh pembelajar bahasa secara wajar tanpa ada kesulitan dalam berkomunikasi atau berbahasa. Penguasaan kosa kata pasifreseptif merupakan kosa kata yang telah dikuasai, hanya dapat dipahami oleh pembelajar bahasa dari ungkapan bahasa orang lain, tetapi ia tidak mampu menggunakan kosa kata secara wajar dalam berkomunikasi atau berbahasa.

Anak Usia Dini merupakan usia yang sangat efektif untuk mengembangkan berbagai potensi yang dimiliki, termasuk pengembangan bahasa melalui kosa kata. Upaya pengembangan ini dapat dilakukan dengan berbagai cara, salah satunya melalui kegiatan bermain peran. Kegiatan bermain peran harus dilakukan secara menarik dan menyenangkan, agar anak dapat tertarik dengan apa yang guru sajikan.

Dunia anak adalah dunia bermain. Bermain bagi anak merupakan kesukaan anak usia dini karena secara normal tidak ada seorang anak pun yang tidak suka 
bermain. Maka pembelajaran kemampuan kosa kata dilakukan dengan cara yang menarik dan menyenangkan.

Melalui bermain anak akan menjelajahi dunianya dan memperoleh manfaat belajar sesuatu yang baru. (Ramli, 2018) bahwa belajar merupakan perubahan pada diri seseorang. Bermain merupakan kebahagiaan bagi anak-anak karena dengan bermain mereka bisa mengekspresikan berbagai perasaannya serta belajar berkomunikasi dan beradaptasi dengan lingkungannya.

Berdasarkan hasil observasi awal pada tanggal 02 Desember 2019 sampai pada tanggal 06 Desember 2019, di TK AL-AMIN mengenai kemampuan kosa kata anak pada kelompok A menjelaskan fenomena yang terjadi yakni ada beberapa anak yang masih kesulitan dalam berbicara bahkan ada anak yang berbicara melalui bahasa tubuhnya seperti menggelengkan kepala dan menunjuk menggunakan jari tangan. Hal ini dapat dilihat saat guru memberikan pertanyaan secara lisan kepada anak mengenai kesehariannya. Dan saat guru berbicara atau bercerita anak-anak menangkap isi pesan dan memahami makna komunikasi yang disampaikan oleh guru. Tetapi ketika anak diminta untuk menceritakan kembali apa yang disampaikan guru, masih belum lancar, masih ada jeda lama ketika anak bercerita. Jadi penguasaan kosa kata anak masih belum berkembang dan memerlukan peningkatan. Hal ini dilihat dari beberapa anak yang belum mampu mengungkapkan ide menggunakan kalimat sederhana dan menceritakan kembali apa yang di ceritakan oleh guru. Kondisi ini disebabkan karena pembelajaran yang diajarkan menggunakan metode ceramah, metode bercakap-cakap, dan metode tanya jawab. Sementara pembelajaran kemampuan kosa kata jarang digunakan melalui pembelajaran kegiatan bermain peran di TK Al-Amin Kota Palopo.

Dengan metode bermain peran akan menjadi suatu hal yang menarik perhatian anak karena bermain peran memberikan ruang berimajinasi dan berekspresi bagi anak sehingga dapat meningkatkan percaya dirinya dan memperluas kosa kata. Bermain peran adalah anak-anak bermain berpura-pura menjadi sesuatu seperti benda, binatang, atau tokoh.

Menurut Nugraha dalam Aida, dkk. (2015:91) "Anak senang bermain "khayalan" berakting sebagai orang tua, meniru tokoh kartun atau menjadi bayi". Main peran melibatkan interaksi secara verbal atau bercakap-cakap, dan interaksi dengan orang lain. Sedangkan menurut Khoiruddin dalam Nurfauziah (2013:5) "Bermain peran disebut juga bermain simbolik, pura-pura, fantasi, imajinasi, atau bermain drama".

Menurut Erikson dalam Nurfauziah (2013:5) terdapat dua jenis bermain peran, yaitu bermain peran mikro dan makro. Berikut penjelasan dari bermain peran makro dan bermain peran mikro. Mutiah (2010:115) mengatakan bermain peran makro adalah anak berperan sesungguhnya dan menjadi seseorang atau sesuatu. Saat anak memiliki pengalaman sehari-hari dengan main peran makro (tema sekitar kehidupan nyata), mereka belajar banyak keterampilan praakademis seperti: mendengarkan, tetap dalam tugas, menyelesaikan masalah, dan bermain kerja sama dengan yang lain. Sedangkan main peran mikro adalah anak memegang atau menggera-gerakkan benda-benda berukuran kecil untuk menyusun adegan. Saat anak main peran mikro, mereka belajar untuk menghubungkan dan mengambil sudut pandang dari orang lain.

\section{Metode}


Penelitian ini akan dilakukan dengan desain Penelitian Tindakan Kelas (PTK). Pendekatan yang digunakan dalam penelitian ini adalah pendekatan kualitatif bertujuan untuk menggambarkan keadaan atau status fenomena. Suhardjono dalam Dimyati (2013:118) memberi pengertian penelitian tindakan kelas, yakni penelitian yang dilaksanakan oleh guru, bekerja sama dengan peneliti atau dilakukan oleh guru sendiri yang juga bertindak sebagai peneliti di kelas atau di sekolah tempat kerjanya, dengan penekanan pada penyempurnaan atau peningkatan proses dan hasil pembelajaran. Dengan tujuan untuk memperbaiki mutu praktik pembelajaran dikelas. Bahkan menurut McNiff menjelaskan bahwa penelitian tindakan kelas sebagai bentuk penelitian reflektif yang dilakukan oleh pendidik sendiri terhadap kurikulum, pengembangan sekolah, meningkatkan prestasi belajar, pengembangan keahlian mengajar, dan sebagainya.

Penelitian dilakukan pada kelompok A di TK Al-Amin Kota Palopo yang beralamat di Jl. Danau Tondano II, Btn. Hartaco, Kelurahan Benteng, Kecamatan Wara Timur Kota Palopo. Penelitian tindakan kelas ini dilaksanakan pada tanggal 10 Agustus - 09 September 2020. Subjek pada penelitian ini yaitu anak kelompok A di TK Al-Amin Kota Palopo yang berjumlah 10 orang anak yang terdiri dari 2 orang anak laki-laki dan 8 orang anak perempuan.

Adapun tahapan pelaksanaan penelitian

1. Perencanaan, tahap perencanaan dalam penelitian ini akan dilaksanakan dengan langkah-langkah berikut:
a. Menyusun Rencana Pelaksanaan Pembelajaran Harian (RPPH)
b. Merancang Skenario bermain peran
c. Mempersiapkan media yang akan digunakan dalam pembelajaran
d. Mempersiapkan lembar observasi.

2. Pelaksanaan, tindakan dilaksanakan berdasarkan kolaborasi antara guru dan peneliti dalam melaksanakan tindakan yang telah direncanakan. Penelitian ini direncanakan akan melalui dua siklus, siklus I dan siklus II. Tindakan tidak mutlak dikendalikan oleh rencana, hal ini mengandung resiko karena terjadi dalam kondisi nyata. Karena itu rencana tindakan harus bersifat sementara, fleksibel, dan siap diubah sesuai dengan kondisi yang ada sebagai usaha ke arah perbaikan.

Adapun proses tindakannya meliputi:
a. Mengatur ruang kelas
b. Menyiapkan alat yang digunakan dalam kegiatan bermain peran
c. Mengumpulkan anak untuk menerangkan teknik bermain peran dengan cara sederhana
d. Pendidik membagikan peran dan tugas kepada anak sebelum bermain peran
e. Anak bermain sesuai tempatnya
f. Pendidik hanya mengawasi dan mendampingi anak dalam bermain, apabila dibutuhkan anak, pendidik dapat membantu
g. Peneliti menghentikan kegiatan bermain peran pada saat situasi tertentu dan kemudian membuka diskusi umum
h. Sebagai hasil diskusi, peneliti dapat meminta pendapat kepada peserta didik untuk menyimpulkan pemecahan masalah yang terjadi pada saat bermain peran.

3. Pengamatan

Pengamatan dilakukan selama proses tindakan berlangsung dengan menggunakan instrument penilaian dan catatan mengenai perkembangan anak, yaitu mengenai kemampuan kosa kata anak. Peneliti mencatat dengan cermat apa yang terjadi selama proses kegiatan pembelajaran bermain peran agar memperoleh data yang akurat.

4. Refleksi 
Refleksi dilakukan untuk mengevaluasi hasil tindakan yang telah dilakukan dengan mengacu pada hasil pengamatan dan wawancara. Berdasarkan hasil refleksi tindakan yang dilaksanakan pada siklus sebelumnya, dilakukan perbaikan pelaksanaan pembelajaran pada siklus berikutnya. Pelaksanaan tindakan pada siklus berikutnya disesuaikan dengan perubahan yang ingin dicapai. Hasil yang ingin dicapai pada siklus ini dikumpulkan serta dianalisis untuk menentukan suatu kesimpulan.

Tekhnik pengumpulan data yang digunakan dalam penelitian ini adalah pengamatan, wawancara, dan dokumentasi.

Instrumen dalam penelitian ini menggunakan lembar observasi berupa instrumen untuk mencatat kemampuan kosa kata anak melalui kegiatan bermain peran.

Tabel 1. Kisi-kisi Penilaian Kemampuan Kosakata Anak

\begin{tabular}{|l|l|}
\hline \multicolumn{1}{|c|}{ Indikator } & \multicolumn{1}{|c|}{ Aspek yang di nilai } \\
\hline $\begin{array}{l}\text { Kemampuan anak dalam } \\
\text { mengucapkan kalimat sederhana } \\
\text { (6 kata) }\end{array}$ & Kemampuan anak dalam mengucapkan 2 kata \\
\cline { 2 - 2 } & Kemampuan anak dalam mengucapkan 4 kata \\
\cline { 2 - 2 } & Kemampuan anak dalam mengucapkan 6 kata \\
\hline
\end{tabular}

Analisis data dalam penelitian ini juga dilakukan dengan menggunakan penelitian kuantitatif. Data yang dikumpulkan pada setiap kegiatan observasi dari setiap pelaksanaan siklus dianalisis secara deskriptif kuantitatif dengan menggunakan teknik persentase untuk melihat kecenderungan yang terjadi dalam kegiatan pembelajaran. Data yang diperoleh dideskripsikan dalam bentuk narasi sehingga data mudah dipahami dan tersusun dengan baik. Selanjutnya, membuat kesimpulan berdasarkan deskripsi data, sejauh mana peningkatan kemampuan motorik halus anak yang dicapai dalam pembelajaran.

Haeruddin (2014:40) Indikator keberhasilan yang ingin dicapai dalam penelitian ini adalah apabila $70 \%$ anak didik telah berhasil mencapai kategori berkembang sesuai harapan dalam hal peningkatan kemampuan kosa kata anak.

\section{Hasil dan Pembahasan}

Dalam bab ini akan dideskripsikan mengenai hasil pengolahan dan pembahasan penelitian yang memperhatikan peningkatan kemampuan kosa kata anak melalui kegiatan bermain peran. Data tentang hasil penelitian diperoleh melalui lembar observasi dan dokumentasi. TK. Al-Amin Palopo beralamat di Btn. Hartaco, Kelurahan Benteng, Kecamatan Wara Timur, Kota Palopo. TK. Al-Amin tergolong cukup strategis karena terletak di antara rumah penduduk.

\section{Pra Siklus}

Sebelum dilakukan penelitian tindakan kelas, terlebih dahulu peneliti mengamati anak yang sedang belajar mengucapkan dan mengingat kosa kata yang ada disekitarnya pada kelompok A di TK. Al-Amin Kota Palopo yang berjumlah 10 orang anak pada kegiatan awal hasil pengamatan tersebut. Dalam penelitian ini, peneliti membuat kategori penilaian kemampuan kosa kata anak menjadi 4 kriteria dengan skor minimal 3 dan skor maksimal 9. Berdasarkan data bahwa kemampuan pencapaian kemampuan kosa kata anak masih perlu ditingkatkan. Hal ini dilihat indikator penilaian yang terdiri dari 3 aspek. Aspek penilaian yang pertama yaitu kemampuan anak dalam mengucapkan 2 kata terdapat dua orang anak atau sekitar $20 \%$ yang memperoleh skor 1 , lima orang anak atau sekitar $50 \%$ mendapatkan skor 2, tiga orang anak atau sekitar 30\% mendapatkan skor 3 dan tidak seorang anak pun yang mendapatkan skor 4. Pada aspek penilaian yang kedua yaitu 
kemampuan anak dalam mengucapkan 4 kata terdapat empat orang anak atau sekitar $40 \%$ mendapatkan skor 1dan skor 2 , dua orang anak atau sekitar 20\% mendapatkan skor 3 dan tidak seorang anak pun yang mendapatkan skor 4. Pada aspek penilaian yang ketiga yaitu kemampuan anak dalam mengucapkan 6 kata terdapat lima orang anak atau sekitar 50\% mendapatkan skor 1, tiga orang anak atau sekitar 30\% mendapatkan skor 2, dua orang anak atau sekitar 20\% mendapatkan skor 3 dan tidak ada anak yang mendapatkan skor 4 .

Berdasarkan data menunjukkan bahwa kemampuan kosa kata anak yang belum berkembang (BB) sebanyak lima orang atau sekitar 50\%, mulai berkembang (MB) sebanyak tiga orang anak atau sekitar 30\% dan berkembang sesuai harapan (BSH) hanya dua anak atau sekitar 20\% saja. Dari hasil observasi yang dilakukan masih banyak anak berada pada kategori belum berkembang itu artinya bahwa kemampuan kosa kata anak kelompok A di TK Al-Amin Kota Palopo dalam kriteria kurang/rendah. Pelaksanaan tindakan kelas pada siklus I dilaksanakan pada tanggal 11, 13, 15, 18 dan 22 Agustus 2020 yang dilakukan dalam lima kali pertemuan. Adapun hasil penelitian tindakan pada siklus I meliputi: perencanaan tindakan, pelaksanaan tindakan, observasi, dan refleksi yang diuraikan sebagai berikut:

\section{Perencanaan Tindakan Siklus 1} berikut:

Pada tahap rencana tindakan siklus I, hal-hal yang dilakukan peneliti adalah sebagai

a) Melakukan koordinasi dengan guru pendamping sebagai kolaborator peneliti yaitu sebagai pelaksana tindakan.

b) Menyusun RPPH dengan tema Diriku dan sub tema Lingkunganku (Keluargaku).

c) Mempersiapkan bahan dan alat dalam kegiatan bermain peran.

d) Menyiapkan lembar observasi dan lembar catatan yang akan digunakan dalam mengamati kemampuan kosa kata anak dalam kegiatan bermain peran.

e) Menyiapkan kamera sebagai alat dokumentasi kegiatan anak.

Penelitian ini dilaksanakan secara kolaboratif antara guru kelas dengan peneliti, disesuaikan dengan RPPH yang telah disusun oleh peneliti yang sudah didiskusikan dengan guru kelas serta Kepala TK.

Pada setiap pertemuan di kegiatan awal dimulai dengan guru mengucap salam dan dijawab oleh anak-anak, dilanjutkan dengan berdoa bersama sebelum belajar. Selesai berdoa guru menanyakan kabar anak-anak hari ini. Setelah itu anak-anak diajak bernyanyi untuk membangkitkan semangat. Kemudian guru melakukan apersepsi tentang tema kegiatan pembelajaran.

Pada kegiatan inti, peneliti dan kolaborator (guru) menentukan tema kegiatan bermain peran, kemudian mempersiapkan bahan dan alat yang akan digunakan untuk kegiatan bermain peran seperti kostum dan peralatan. Selanjutnya membagi anak kedalam dua kelompok. Setiap kelompok mendapatkan giliran untuk tampil dengan alur cerita yang sama. Hal ini dilakukan agar semua anak dapat berperan aktif dalam kegiatan bermain peran, sehingga dapat mengembangkan kemampuan kosa kata anak. Guru menjelaskan alur cerita yang akan dimainkan oleh anak terlebih dahulu sebelum melakukan kegiatan bermain peran dengan memberikan kebebasan kepada anak dalam membuat dialognya sendiri. Peneliti dan kolaborator mengarahkan anak untuk mengambil posisinya masingmasing sesuai dengan pembagian peran yang sudah ditentukan, sedangkan anak yang belum mendapatkan giliran tampil akan mengamati berlangsungnya kegiatan bermain peran. Guru memberikan kesempatan kepada anak untuk bertanya khususnya kepada anak yang terlibat dalam pemeranan apabila masih ada yang belum dimengerti. Kemudian guru memberikan motivasi dan semangat kepada anak sebelum melakukan kegiatan bermain 
peran agar anak merasa lebih percaya diri untuk tampil didepan teman-temannya. Masingmasing anak mengambil posisi untuk memulai kegiatan bermain peran. Selama kegiatan bermain peran berlangsung peneliti dan kolaborator mengawasi dan membimbing anak yang masih merasa takut atau kurang percaya diri dalam memainkan perannya. Peneliti dan kolaborator menghentikan kegiatan bermain peran karena waktu bermain sudah habis dan mengajak anak-anak untuk bernyanyi bersama agar anak kembali bersemangat setelah selesai melakukan kegiatan bermain peran. Kegiatan telah selesai, anak dipersilahkan untuk mencuci tangannya kemudian dipersilahkan untuk beristirahat dan makan bersama. Setelah itu anak-anak di minta untuk mencuci tangan setelah makan dan dipersilahkan ke kamar mandi/wc bagi yang ingin pipis/buang air kecil ataupun buang air besar.

Pada kegiatan Penutup, Guru mengakhiri pembelajaran hari ini dan mengajak anakanak untuk membereskan perlengkapan yang digunakan dalam kegiatan bermain peran, kemudian berkumpul kembali untuk memberikan penguatan kepada anak. Guru mengajak anak-anak tanya jawab tentang kegiatan hari ini. Kegiatan ditutup dengan berdoa sesudah belajar. Selesai berdo'a guru mengucap salam, anak-anak menjawab salam. Anak-anak kemudian keluar kelas dengan tertib sambil berjabat tangan dengan guru.

\section{Observasi Pelaksanaan Siklus I}

Kegiatan observasi yang diamati oleh peneliti dan kolabolator adalah ketika kegiatan anak berlangsung. Adapun aspek yang diamati meliputi kemampuan anak dalam mengucapkan 2 kata, kemampuan anak dalam mengucapkan 4 kata dan kemampuan anak dalam mengucapkan 6 kata. Berdasarkan data bahwa pencapaian kemampuan kosa kata anak sudah mengalami peningkatan. Hal ini dilihat dari indikator penilaian yang terdiri dari 3 aspek. Aspek penilaian yang pertama yaitu kemampuan anak dalam mengucapkan 2 kata sudah tidak ada anak yang mendapatkan skor 1 , satu orang anak atau sekitar $10 \%$ mendapatkan skor 2, lima orang anak atau sekitar 50\% mendapatkan skor 3 dan empat orang anak atau sekitar $40 \%$ mendapatkan skor 4 . Pada aspek penilaian yang kedua yaitu kemampuan anak dalam mengucapkan 4 kata sudah tidak ada anak yang mendapatkan skor 1, dua orang anak atau sekitar $20 \%$ mendapatkan skor 2, enam orang anak atau sekitar $60 \%$ mendapatkan skor 3 dan dua orang anak atau sekitar 20\% mendapatkan skor 4 . Pada aspek penilaian yang ketiga yaitu kemampuan anak dalam mengucapkan 6 kata, satu orang anak atau sekitar $10 \%$ yang mendapatkan skor 1, dua orang anak atau sekitar $20 \%$ mendapatkan skor 2, lima orang anak atau sekitar 50\% mendapatkan skor 3 dan dua orang anak atau sekitar $20 \%$ yang mendapatkan skor 4 .

Dari hasil pelaksanaan Siklus 1 tersebut dapat disimpulkan bahwa kemampuan kosa kata anak sudah mengalami peningkatan yang cukup baik karena sudah ada anak yang berada dalam kategori berkembang sangat baik (BSB). Berdasarkan data menunjukkan bahwa satu orang anak atau sekitar 10\% masih dalam kategori belum berkembang (BB), sebanyak dua orang anak atau sekitar 20\% dalam kategori mulai berkembang (MB), sebanyak lima anak atau sekitar 50\% dalam kategori berkembang sesuai harapan (BSH) dan sebanyak dua anak atau sekitar 20\% dalam kategori berkembang sangat baik (BSB). Meskipun sudah mengalami peningkatan yang cukup baik, akan tetapi tingkat keberhasilan yang sudah ditargerkan belum tercapai, sehingga penelitian ini harus dilanjutkan ke siklus II.

\section{Refleksi}

Refleksi pada siklus I dilakukan oleh peneliti dan guru pendamping pada akhir siklus I. Kegiatan refleksi ini dilakukan untuk membahas hal-hal yang menjadi hambatan atau hal-hal yang belum dilakukan pada pelaksanaan siklus I dan digunakan sebagai bahan 
masukan pada perencanaan siklus selanjutnya. Dari refleksi siklus I ini, diharapkan dapat memberikan perubahan yang lebih baik terhadap proses pembelajaran dan hasil siklus II.

\section{Perencanaan Tindakan Siklus II}

Setelah berdiskusi dengan kolaborator, maka dapat disusun suatu landasan sebagai penyempurnaan pada tindakan siklus berikutnya antara lain:

a) Untuk meningkatan kelancaran keberlangsungan proses pembelajaran, peneliti dengan kolaborator membuat kesepakatan jika anak dapat mengikuti kegiatan dengan baik akan diberikan reward.

b) Guru memberikan kesempatan pada anak untuk bertanya jika masih belum memahami akan perintah yang diberikan oleh guru sebelum anak melakukan kegiatan.

c) Guru menetapkan aturan pada saat bermain peran agar nantinya anak-anak mengerti aturan pada saat bermain peran dengan demikian kegiatan bermain peran dapat berjalan dengan baik.

d) Untuk menarik perhatian anak peneliti mengganti tema yang akan di gunakan dalam kegiatan bermain peran.

Penelitian ini dilaksanakan secara kolaboratif antara guru kelas dengan peneliti, disesuaikan dengan RPPH yang telah disusun oleh peneliti yang sudah didiskusikan dengan guru kelas serta Kepala TK.

Pada setiap pertemuan di kegiatan awal dimulai dengan guru mengucap salam dan dijawab oleh anak-anak, dilanjutkan dengan berdoa bersama sebelum belajar. Selesai berdoa guru menanyakan kabar anak-anak hari ini. Setelah itu anak-anak diajak bernyanyi untuk membangkitkan semangat. Kemudian guru melakukan apersepsi tentang tema kegiatan pembelajaran.

Pada kegiatan inti, peneliti dan kolaborator (guru) menentukan tema kegiatan bermain peran, kemudian mempersiapkan bahan dan alat yang akan digunakan untuk kegiatan bermain peran seperti kostum dan peralatan. Selanjutnya membagi anak kedalam dua kelompok. Setiap kelompok mendapatkan giliran untuk tampil dengan alur cerita yang sama. Hal ini dilakukan agar semua anak dapat berperan aktif dalam kegiatan bermain peran, sehingga dapat mengembangkan kemampuan kosa kata anak. Guru menjelaskan alur cerita yang akan dimainkan oleh anak terlebih dahulu sebelum melakukan kegiatan bermain peran dengan memberikan kebebasan kepada anak dalam membuat dialognya sendiri. Peneliti dan kolaborator mengarahkan anak untuk mengambil posisinya masingmasing sesuai dengan pembagian peran yang sudah ditentukan, sedangkan anak yang belum mendapatkan giliran tampil akan mengamati berlangsungnya kegiatan bermain peran. Guru memberikan kesempatan kepada anak untuk bertanya khususnya kepada anak yang terlibat dalam pemeranan apabila masih ada yang belum dimengerti. Kemudian guru memberikan motivasi dan semangat kepada anak sebelum melakukan kegiatan bermain peran agar anak merasa lebih percaya diri untuk tampil didepan teman-temannya. Masingmasing anak mengambil posisi untuk memulai kegiatan bermain peran. Selama kegiatan bermain peran berlangsung peneliti dan kolaborator mengawasi dan membimbing anak yang masih merasa takut atau kurang percaya diri dalam memainkan perannya. Peneliti dan kolaborator menghentikan kegiatan bermain peran karena waktu bermain sudah habis dan mengajak anak-anak untuk bernyanyi bersama agar anak kembali bersemangat setelah selesai melakukan kegiatan bermain peran. Kegiatan telah selesai, anak dipersilahkan untuk mencuci tangannya kemudian dipersilahkan untuk beristirahat dan makan bersama. Setelah itu anak-anak di minta untuk mencuci tangan setelah makan dan dipersilahkan ke kamar mandi/wc bagi yang ingin pipis/buang air kecil ataupun buang air besar.

Pada kegiatan Penutup, Guru mengakhiri pembelajaran hari ini dan mengajak anakanak untuk membereskan perlengkapan yang digunakan dalam kegiatan bermain peran, 
kemudian berkumpul kembali untuk memberikan penguatan kepada anak. Guru mengajak anak-anak tanya jawab tentang kegiatan hari ini. Kegiatan ditutup dengan berdoa sesudah belajar. Selesai berdo'a guru mengucap salam, anak-anak menjawab salam. Anak-anak kemudian keluar kelas dengan tertib sambil berjabat tangan dengan guru.

Kegiatan observasi yang diamati oleh peneliti dan kolabolator adalah ketika kegiatan anak berlangsung. Adapun aspek yang diamati meliputi kemampuan anak dalam mengucapkan 2 kata, kemampuan anak dalam mengucapkan 4 kata dan kemampuan anak dalam mengucapkan 6 kata.

Berdasarkan data diperoleh data bahwa pencapaian kemampuan kosa kata anak sudah mengalami peningkatan yang sangat pesat. Hal ini dilihat dari indikator penilaian yang terdiri dari 3 aspek. Aspek penilaian yang pertama yaitu kemampuan anak dalam mengucapkan 2 kata sudah tidak ada anak yang mendapatkan skor 1, 2 dan 3, 10 orang anak atau sekitar $100 \%$ mendapatkan skor 4. Pada aspek penilaian yang kedua yaitu kemampuan anak dalam mengucapkan 4 kata sudah tidak ada yang mendapatkan skor 1 dan 2, tiga orang anak atau sekitar $30 \%$ mendapatkan skor 3 , tujuh orang anak atau sekitar $70 \%$ mendapatkan skor 4 . Pada aspek penilaian yang ketiga yaitu kemampuan anak dalam mengucapkan 6 kata sudah tidak ada anak yang mendapatkan skor 1 dan 2 , tujuh orang anak atau sekitar $70 \%$ mendapatkan skor 3, tiga orang anak atau sekitar $30 \%$ mendapatkan skor 4.

Berdasarkan data menunjukkan bahwa sudah tidak ada anak dalam kategori belum berkembang (BB) dan masih berkembang (MB), sebanyak tujuh anak atau sekitar $70 \%$ dalam kategori berkembang sesuai harapan (BSH) dan sebanyak tiga anak atau sekitar $30 \%$ dalam kategori berkembang sangat baik (BSB).

\section{Refleksi}

Refleksi siklus II dilakukan peneliti bersama kolabolator untuk melakukan penilaian selama proses kegiatan bermain peran. Setelah dilaksanakan tindakan pelaksanakan siklus II ini dapat diketahui bahwa kemampuan kosa kata anak mengalami peningkatan sangat baik.

\section{Pembahasan Hasil Penelitian}

Penelitian yang dilakukan ini adalah penelitian tindakan kelas yang dilakukan dalam dua kali siklus yaitu siklus I dan siklus II. Setiap siklus terdiri dari perencanaan, pelaksanaan, pengamatan/observasi dan refleksi. Setiap siklus terdiri dari lima kali pertemuan. Pada siklus II merupakan perbaikan-perbaikan dari siklus I. Hasil yang diperoleh dari penelitian ini adalah berupa hasil pengamatan tentang kemampuan kosa kata anak. Menurut Soedjito dan Saryono dalam Widiyaningsih (2017:13) Kosa kata adalah pembendaharaan kata atau kekayaan kata yang dimiliki oleh suatu bahasa. Penguasaan kosa kata dapat mempengaruhi keterampilan berbahasa seseorang.

Kemampuan kosa kata anak kelompok A di TK Al-Amin Kota Palopo pada kemampuan awal atau sebelum dilakukan tindakan kemampuan kosa kata anak masih tergolong rendah. Hal ini terbukti dari hasil observasi pada kemampuan awal yang dilakukan oleh peneliti. Berdasarkan hasil observasi tersebut, maka peneliti memutuskan untuk lebih mengoptimalkan kemampuan penguasaan kosa kata anak dengan menerapkan metode bermain peran. Adapun indikator yang digunakan sebagai aspek penilaian yaitu 1). kemampuan anak dalam mengucapkan 2 kata, 2). kemampuan anak dalam mengucapkan 4 kata, 3). kemampuan anak dalam mengucapkan 6 kata.

Hasil penelitian tindakan kelas yang dilakukan selama 2 siklus menunjukkan bahwa kemampuan kosa kata anak mengalami peningkatan dari kondisi awal sebelum diadakan penelitian tindakan kelas hingga penelitian tindakan kelas siklus II tahap akhir. Pada kondisi awal terdapat lima $(50 \%)$ anak dengan kategori belum berkembang (BB) mengalami penurunan pada siklus I menjadi satu anak (10\%) dan pada siklus II sudah tidak terdapat lagi anak dengan kategori belum berkembang. Untuk kategori mulai berkembang (MB) pada kondisi awal terdapat tiga anak (30\%), pada siklus I mengalami penurunan menjadi dua anak (20\%), dan pada siklus II tidak terdapat lagi anak dengan kategori mulai berkembang. Kategori berkembang sesuai harapan (BSH) mengalami peningkatan dari kondisi awal ada dua anak (20\%), pada siklus I naik menjadi lima anak (50\%), 
dan pada siklus II lebih meningkat lagi menjadi tujuh anak (70\%), sedangkan untuk kategori berkembang sangat baik (BSB) mengalami peningkatan dari kondisi awal tidak ada, pada siklus I naik menjadi dua anak (20\%), dan pada siklus II naik menjadi tiga anak (30\%). Hal ini menunjukkan bahwa indikator keberhasilan yang telah ditetapkan sebelumnya sudah tercapai dengan baik, dimana sudah terdapat tujuh anak (70\%) dalam kategori berkembang sesuai harapan (BSH).

Berdasarkan hasil penelitian dan didukung dengan teori yang telah dipaparkan sebelumnya maka dapat disimpulkan bahwa melalui kegiatan bermain peran dapat meningkatkan kemampuan kosa kata anak khususnya pada anak kelompok A di TK Al-Amin Kota Palopo.

\section{Simpulan}

Berdasarkan hasil penelitian yang telah dilaksanakan, maka dapat ditarik kesimpulan sebagai berikut :

1. Hasil observasi sebelum dilakukan tindakan (pra siklus) menunjukkan bahwa kemampuan kosa kata anak yang belum berkembang (BB) sebanyak lima orang atau sekitar 50\%, masih berkembang (MB) sebanyak tiga orang anak atau sekitar 30\% dan berkembang sesuai harapan (BSH) hanya dua anak atau sekitar $20 \%$.

2. Hasil observasi pada siklus I menunjukkan bahwa sudah tidak ada anak dalam kategori belum berkembang (BB), sebanyak dua orang anak atau sekitar 20\% dalam kategori masih berkembang (MB), sebanyak lima anak atau sekitar 50\% dalam kategori berkembang sesuai harapan (BSH) dan sebanyak tiga anak atau sekitar 30\% dalam kategori berkembang sangat baik (BSB).

3. Hasil observasi pada siklus II menunjukkan bahwa sudah tidak ada anak dalam kategori belum berkembang (BB) dan masih berkembang (MB), sebanyak tujuh anak atau sekitar 70\% dalam kategori berkembang sesuai harapan (BSH) dan sebanyak tiga anak atau sekitar 30\% dalam kategori berkembang sangat baik (BSB) .

4. Kemampuan kosa kata anak dapat meningkat melalui kegiatan bermain peran. Hal ini dapat dilihat dari tercapainya indikator keberhasilan yang telah di tetapkan sebelumnya yaitu terdapat $70 \%$ anak dalam kategori berkembang sesuai harapan (BSH). 


\section{Daftar Rujukan}

Aida, N., \& Rini, P. A. (2015). Penerapan Metode Bermain Peran Untuk Meningkatkan Kemampuan Bersosialisasi Pada Pendidikan Anak Usia Dini. Jurnal Psikologi Indonesia, 4 (01), 87-99.

Dimyati, J. (2013). Metodologi Penelitian Pendidikan dan Aplikasinya Pada Pendidikan Anak Usia Dini (PAUD). Jakarta: Kencana.

Markus, N., Kusmiyati, \& Sucipto. (2017).Penguasaan Kosa Kata Bahasa Indonesia Anak Usia 4-5 Tahun. Jurnal Ilmiah: Fenomena, 4 (2), 102-115.

Mutiah, D. (2010). Psikologi Bermain Anak Usia Dini. Jakarta: Prenada Media Group.

Nurfauziah, E. (2013). Pengaruh Bermain Peran Makro Terhadap Penguasaan Kosa Kata Bahasa Inggris di Taman Kanak-kanak. Skripsi. Program Studi Pendidikan Guru Pendidikan Anak Usia Dini Universitas Pendidikan Indonesia.

Ramli, S. A. (2018). Penerapan Pendekatan Kooperatif Tipe TGT Pada Pembelajaran SAINS dalam Meningkatkan Hasil Belajar Anak di Kota makassar. PiJIES: Pedagogik Journal of Islamic Elementary School, 194.

Widyaningsih. (2017). Peningkatan Penguasaan Kosa Kata Melalui Penggunaan Media Gambar Seri pada Anak Kelompok B di TK ABA Miliaran Muja Muju Umbul Harjo, Yogyakarta. Skripsi. Program Studi Pendidikan Guru Pendidikan Anak Usia Dini Universitas Negeri Yogyakarta. Yogyakarta. 